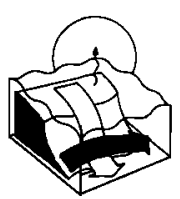

\title{
Three hundred eighty thousand year long stable isotope and faunal records from the Red Sea: Influence of global sea level change on hydrography
}

\author{
Christoph Hemleben, ${ }^{1}$ Dieter Meischner, ${ }^{2}$ Rainer Zahn, ${ }^{3}$ Ahuva Almogi-Labin, ${ }^{4}$
} Helmut Erlenkeuser, ${ }^{5}$ and Birgit Hiller ${ }^{1}$

\begin{abstract}
Stable isotope and faunal records from the central Red Sea show high-amplitude oscillations for the past 380,000 years. Positive $\delta{ }^{18} \mathrm{O}$ anomalies indicate periods of significant salt buildup during periods of lowered sea level when water mass exchange with the Arabian Sea was reduced due to a reduced geometry of the Bab el Mandeb Strait. Salinities as high as $\mathbf{5 3} \%$ and $\mathbf{5 5 \%}$ are inferred from pteropod and benthic foraminifera $\delta^{18} \mathrm{O}$, respectively, for the last glacial maximum. During this period all planktonic foraminifera vanished from this part of the Red Sea. Environmental conditions improved rapidly after $13 \mathrm{ka}$ as salinities decreased due to rising sea level. The foraminiferal fauna started to reappear and was fully reestablished between $9 \mathrm{ka}$ and $8 \mathrm{ka}$. Spectral analysis of the planktonic $\delta^{18} \mathrm{O}$ record documents highest variance in the orbital eccentricity, obliquity, and precession bands, indicating a dominant influence of climatically - driven sea level change on environmental conditions in the Red Sea. Variance in the precession band is enhanced compared to the global mean marine climate record (SPECMAP), suggesting an additional influence of the Indian monsoon system on Red Sea climates.
\end{abstract}

\section{Introduction}

Quantitative studies and isotopic analyses of planktonic foraminifera and pteropoda from the Red Sea revealed a detailed picture of water mass variation in association with global climatic changes during the latest Pleistocene (from isotope stage 6 onward) and early Holocene [Herman, 1968; Chen, 1969; Deuser and Degens, 1969; Deuser et al., 1976; Risch, 1976; Yusuf, 1978; Reiss et al., 1980; Almogi-Labin, 1982; Ivanova, 1985; Almogi-Labin et al., 1986, 1991; Locke and Thunell, 1988; Thunell et al. 1988]. During the last glacial maximum (LGM), approximately 18,000 years ago, surface and intermediate water salinities were significantly higher than they are today. Only one pteropod species, Creseis acicula, survived while planktonic foraminifera vanished almost entirely from the Red Sea, resulting in an "aplanktonic

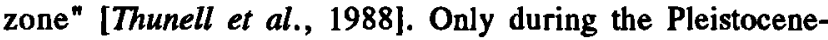
Holocene transition period did the planktonic fauna slowly migrate back from the Gulf of Aden into the Red Sea. These

\footnotetext{
'Institute and Museum for Geology and Paleontology, University of Tübingen, Tübingen, Germany.

${ }^{2}$ Department of Sedimentary Geology, Institute for Geology and Paleontology, University of Göttingen, Göttingen, Germany.

${ }^{3}$ GEOMAR, Research Center for Marine Geosciences, Kiel, Germany.

${ }^{4}$ Geological Survey of Israel, Jerusalem.

sInstitut für Reine und Angewandte Kernphysik, Kiel, Germany.
}

Copyright 1996 by the American Geophysical Union.

Paper number 95PA03838.

0883-8305/96/95PA-03838 $\$ 10.00$ changes have been attributed to the Red Sea, being a marginal sea, which makes its hydrography extremely susceptible to global climate change. Global sea level variations exert additional control on Red Sea hydrography in that they determine the water mass exchange with the open ocean and thus residence time of water masses and salt buildup in the Red Sea [Thunell et al., 1988; Bryden and Kinder, 1991]

Piston cores up to $22 \mathrm{~m}$ long were recovered from the central Red Sea and offshore Sudan during an expedition with the $R / V$ Meteor in 1987. Here we present stable isotope and faunal records of one of these cores from the central Red Sea which span $380 \mathrm{kyr}$ and significantly extend the documented record of environmental change in the Red Sea. The records show that Red Sea climates responded not only to glacialinterglacial conditions but also to higher-frequency variations in the orbital precession band. As only fragmentary continental records are available from the surrounding landmasses, the records may also extend our understanding of the long-term climatic history of this region.

\section{Material and Methods}

We have generated a planktonic stable isotope record and records of foraminiferal abundance and faunal variability along a $21 \mathrm{~m}$ long Meteor Core Sta. 174/KL11 from the central Red Sea $\left(18^{\circ} 46.3^{\prime} \mathrm{N}, 39^{\circ} 19.9^{\prime} \mathrm{E}, 825 \mathrm{~m}\right.$ water depth), hereafter referred to as core $\mathrm{KL} 11$. For $\delta^{18} \mathrm{O}$ measurements we have used the tropical-subtropical planktonic foraminiferal species Globigerinoides ruber (forma white), which dominates the foraminiferal fauna at the site of core KL11. An age scale 


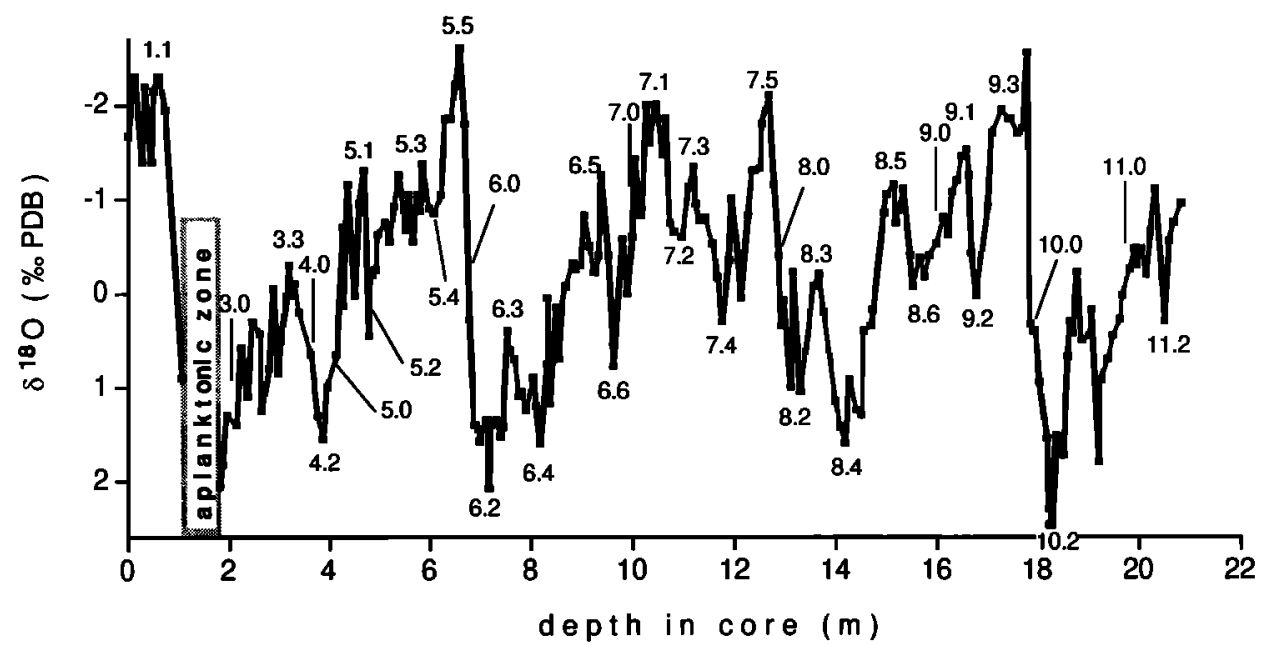

Figure 1. Planktonic (Globigerinoides ruber, white variety) oxygen isotope record of core KL 11. Numbers along the isotope record indicate SPECMAP events after Imbrie et al. [1984] which were used for age control (see Table 1). At core depth of 0.9-1.7 m no planktonic foraminifera were available for isotope measurements due to the "aplanktonic zone" which was caused by extremely high salinities during the last glacial maximum (LGM) at approximately $18 \mathrm{ka}$.

for core KL11 was obtained through correlation of the isotope records with the global mean SPECMAP ${ }^{18} \mathrm{O}$ curve ( Figure 1, Table 1) [Imbrie et al., 1984]. The base of core KL11 reaches SPECMAP interglacial climatic event 11.2, a shortlived cold spell at approximately $375 \mathrm{ka}$ (Figures 1 and 2). The age model suggests that mean sedimentation rates at the core site are $5.6 \mathrm{~cm}$ kyr. The isotope measurements were carried out at the C14-Laboratory at Kiel University using a Finnigan MAT 251 mass spectrometer, which is linked on-line to a fully automated carbonate preparation device. The carbonate samples are dissolved in separate glass vials thus minimizing potential memory effects. Reproducibility was $0.08 \%$, and all isotope values are referred to the Peedee belemnite (PDB) scale. The planktonic foraminiferal counts were done on the size fraction $>150 \mu \mathrm{m}$ and normalized to $1 \mathrm{~g}$ of sediment.

\section{Results}

\section{Stable Isotopes and Hydrography}

The planktonic $\delta^{18} \mathrm{O}$ profile along core KL11 shows highamplitude fluctuations with glacial-interglacial shifts up to 3.5$4.0 \%$ (Figure 2a). The coeval global glacial-interglacial $\delta^{18} \mathrm{O}$ variation of the world ocean's water masses was 1.1-1.2\%o [Labeyrie et al., 1987; Fairbanks, 1989], and thus planktonic $\delta^{18} \mathrm{O}$ amplitudes at core KL11 exceed the mean-ocean change by a factor of 3-4. The glacial-interglacial $\delta^{18} \mathrm{O}$ amplitudes are also about 2 to 3 times larger $\left(\Delta \delta^{18} \mathrm{O}=3-4 \%\right.$ ) than those observed in planktonic $\delta^{18} \mathrm{O}$ records from the Arabian Sea $\left(\Delta \delta^{18} \mathrm{O}=1.1-1.7 \% \mathrm{o}\right)$ [Niitsuma et al., 1991; Zahn and Pedersen, 1991; Sirocko et al., 1993], which may be ascribed to the concentration effect (salt buildup) [cf. Morcos, 1970] of the Red Sea as a marginal sea. In addition, to the glacialinterglacial isotope shifts the $\delta^{18} \mathrm{O}$ record displays highamplitude variations of more than $1 \%$ within glacial and interglacial stages which exceed the degree of variability seen in $\delta^{18} \mathrm{O}$ records at open-ocean sites. For the 'aplanktonic' interval during the LGM no planktonic foraminifera were
Table 1. Stratigraphic Fix Points for Core KL 11

\begin{tabular}{rrrr}
\hline Depth, m & Age, ka & $\begin{array}{c}\text { Deposition } \\
\text { Rate, cm/kyr }\end{array}$ & $\begin{array}{r}\text { SPECMAP } \\
\text { event }\end{array}$ \\
\hline 0.64 & 6 & & 1.1 \\
2.10 & 24 & 8.11 & 3.0 \\
3.23 & 53 & 3.90 & 3.3 \\
3.66 & 59 & 7.17 & 4.0 \\
3.88 & 65 & 3.67 & 4.2 \\
4.16 & 71 & 4.67 & 5.0 \\
4.70 & 80 & 6.00 & 5.1 \\
4.85 & 91 & 1.36 & 5.2 \\
5.65 & 99 & 10.00 & 5.3 \\
6.05 & 109 & 4.00 & 5.4 \\
6.63 & 122 & 4.46 & 5.5 \\
6.70 & 128 & 1.17 & 6.0 \\
7.17 & 135 & 6.71 & 6.2 \\
7.61 & 145 & 4.40 & 6.3 \\
8.20 & 151 & 9.83 & 6.4 \\
9.15 & 174 & 4.13 & 6.5 \\
9.64 & 183 & 5.44 & 6.6 \\
9.97 & 186 & 11.00 & 7.0 \\
10.46 & 194 & 6.13 & 7.1 \\
11.00 & 209 & 3.60 & 7.2 \\
11.30 & 216 & 4.29 & 7.3 \\
11.70 & 228 & 3.33 & 7.4 \\
12.63 & 238 & 9.30 & 7.5 \\
12.96 & 245 & 4.71 & 8.0 \\
13.18 & 249 & 5.50 & 8.2 \\
13.60 & 257 & 5.25 & 8.3 \\
14.28 & 269 & 5.67 & 8.4 \\
15.13 & 287 & 4.72 & 8.5 \\
15.67 & 299 & 4.50 & 8.6 \\
16.00 & 303 & 8.25 & 9.0 \\
16.50 & 310 & 7.14 & 9.1 \\
16.80 & 320 & 3.00 & 9.2 \\
17.48 & 331 & 6.18 & 9.3 \\
17.93 & 339 & 5.62 & 10.0 \\
18.24 & 341 & 15.50 & 10.2 \\
19.73 & 362 & 7.10 & 11.0 \\
20.60 & 375 & 6.69 & 11.2 \\
\hline & & &
\end{tabular}



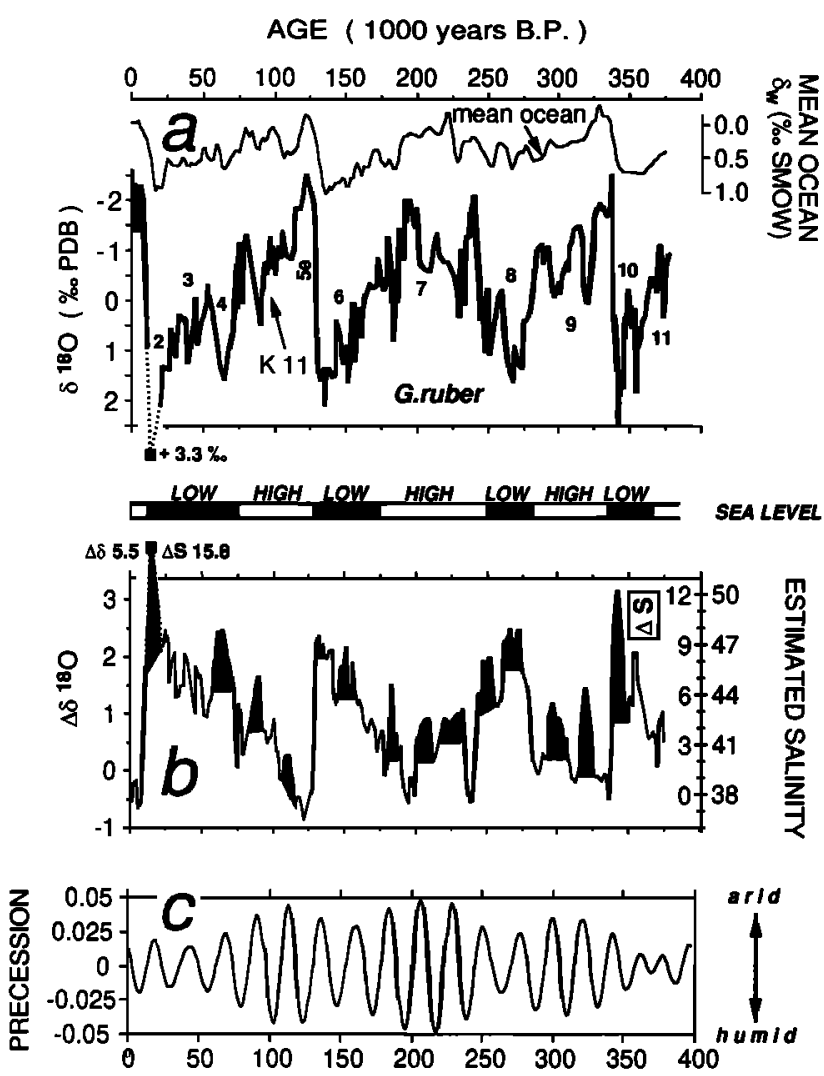

Figure 2. (a) Planktonic $\delta^{18} \mathrm{O}$ record from core $\mathrm{KL} 11$ in the central Red Sea, showing glacial-interglacial amplitudes which are up to 3 times higher than those of the mean-ocean $\delta_{w}$ record (right-hand scale; from Vogelsang, 1990]). The $\delta^{18} \mathrm{O}$ value of $+3.3 \%$ for the aplanktonic zone of the LGM was obtained from planktonic pteropods and is plotted out of scale (see text for description of pteropod versus $G$. ruber $\delta^{18} \mathrm{O}$ calibration). Numbers along the planktonic record indicate oxygen isotope stages. (b) Deviation $\left(\Delta \delta^{18} \mathrm{O}\right)$ of the planktonic $\delta^{18} 0$ record from the mean-ocean $\delta_{w}$ record. Right-hand scales give salinity anomaly $(\Delta S)$ relative to today (modern ) (S set to zero) and absolute salinity estimates. Salinity was estimated using a $\Delta \delta_{w}: \Delta S$ ratio of 0.29 [Craig, 1966]. The shade peaks represent insolation peaks in precession [RossignolStrick,1983]. (c) Precession index of Berger and Loutre [1991]. The $\Delta \delta^{18} \mathrm{O}$ and $\Delta S$ anomalies seen in (Figure $2 b$ ) are coherent with the precession index pointing to low-latitude climatic forcing of the isotope-salinity anomalies, perhaps monsoonal variability. The orbital precession record has been lagged by $3 \mathrm{kyr}$ to account for the phase lag which was determined by cross-spectral analysis (see Figure 5 and Table 2).

available for isotope analysis. For this interval we measured a sample containing three clean aragonitic shells with no secondary aragonite of the planktonic pteropod species Creseis acicula. Sediment trap samples taken off Bermuda have shown that the $\delta^{18} \mathrm{O}$ value of this species is about $0.3 \%$ more negative than the value of aragonite which is precipitated in isotopic equilibrium with ambient seawater temperature and isotope composition [Jasper and Deuser, 1993]. Twenty-six paired isotope measurements on Holocene samples from core KL11 give a mean $\delta^{18} \mathrm{O}$ offset between $C$. acicula and $G$. ruber of $-1.4 \pm 0.12 \%$ (2o). We use this value to convert the $\delta^{18} \mathrm{O}$ value of $+4.7 \%$ which was obtained for the LGM pteropod sample to the $\delta^{18} \mathrm{O}$-scale of $G$. ruber (a bulk sediment sample was measured for reference and gave a $\delta^{18} \mathrm{O}$ value of $+6.3 \%$ ). Thus, we arrive at a $G$. ruber $\delta^{18} \mathrm{O}$ equivalent of $+3.3 \%$ for the LGM. Using this value, a $\delta^{18} \mathrm{O}$ amplitude of $5.5 \%$ is calculated between the LGM and the Holocene, which is the largest amplitude recorded throughout the entire profile.

In order to extract a record of hydrographic variability we have computed the difference between the record of meanocean $\delta^{18} \mathrm{O}\left(\delta_{w}\right)$ from Vogelsang [1990] and the planktonic $\delta^{18} \mathrm{O}$ record from core KL11. Using benthic $\delta^{18} \mathrm{O}$ records from the Norwegian Sea and assuming that bottom water temperature there remained constant through glacial-interglacial times, Vogelsang [1990] composed a record of mean-ocean $\delta^{18} \mathrm{O}\left(\delta_{w}\right)$ change for the last $400 \mathrm{ka}$. This $\delta_{w}$ record (Figure $2 a$, right hand scale) documents global $\delta^{18} \mathrm{O}$ fluctuations of the world ocean's water masses which were driven by the growth and decay of global ice volume in the course of glacial-interglacial climatic change. The mean-ocean $\delta_{w}$ values vary between $-0.2 \% \circ \delta{ }^{18} \mathrm{O}$ and $+1.0 \% \circ \delta{ }^{18} \mathrm{O}$ (SMOW, standard mean ocean water). Cross-spectral coherency is high between the mean-ocean $\delta_{w}$ record and planktonic $\delta^{18} \mathrm{O}$ from core $\mathrm{KL} 11$, thus allowing direct comparison of both records (Table $2)$. The record of planktonic $\delta^{18} \mathrm{O}$ change in excess of the mean-ocean $\delta_{w}$ change is shown in Figure $2 b$. This record shows that the offset $\left(\Delta \delta^{18} 0\right)$ between planktonic $\delta^{8} O$ and mean-ocean $\delta_{w}$ was systematically larger during glacial periods, whereas during full - interglacial periods the offset was similar to or even slightly less than today. Superimposed on the long-term trend are short-lived anomalies which correlate with minima in the orbital precession index, reflecting the influence of precessional variability on low-latitude climate (see below).

The oxygen isotope composition of sea water in the Red Sea changes by $0.29 \%$ for each $1 \%$ change in salinity [Craig, 1966]. Using this slope, we have computed a salinity scale from the $\Delta \delta^{18} \mathrm{O}$ record (Figure 2b, right-hand scale). Inferred glacial-interglacial salinities in the Red Sea varied by up to $10 \%$ during the past 380,000 years. For the LGM the salinity increase was estimated by subtracting $1.2 \%$ from the $\delta^{18} \mathrm{O}$ amplitude of $5.5 \%$ between the LGM and the Holocene to account for global ice volume change. The residue of $4.3 \%$ translates into a salinity change of $14.8 \%$ (i.e., 4.3/0.29). Adding $1 \%$ salinity to allow for a global salinity increase due to the effects of increased ice volume and lower sea level we arrive at an overall salinity increase of $15.8 \%$ o for the LGM. This number is reduced by $1.5-2.0 \%$ (salinity) if we allow for a glacial temperature decrease of $2^{\circ} \mathrm{C}$ [CLIMAP Project Members, 1981; Thunell et al., 1988], which would be equivalent to a $\delta^{18} \mathrm{O}$ increase of $0.5 \%$. Previous studies inferred similar salinity or slighly lower increases for the glacial maximum Red Sea [Berggren and Boersma, 1969; Deuser and Degens, 1969; Deuser et al. 1976; Reiss et al., 1980; Thunell et al., 1988; Almogi-Labin et al., 1991]. Our estimate is supported by abundance changes of planktonic foraminiferal species which are sensitive to salinity changes (see below).

In addition to the planktonic $\delta^{18} \mathrm{O}$ we have generated a benthic $\delta^{18} \mathrm{O}$ record using a combined isotopic record of epibenthic Hanzawaia sp., Cibicides mabahethi in order to 
Table 2. Cross-Spectral Coherence and Phase Angles

\begin{tabular}{llllllc}
\hline & Coherence & $\begin{array}{l}\text { Phase } \\
\text { Angle }\end{array}$ & Coherence & $\begin{array}{l}\text { Phase } \\
\text { Angle }\end{array}$ & Coherence & $\begin{array}{l}\text { Phase } \\
\text { Angle }\end{array}$ \\
\hline Mean ocean $\delta_{w}{ }^{2}$ & 0.877 & $-6^{\circ} \pm 14.8^{\circ}$ & 0.749 & $-15^{\circ} \pm 22^{\circ}$ & 0.760 & $-10^{\circ} \pm 22^{\circ}$ \\
SPECMAP & 0.949 & $-3^{\circ} \pm 9^{\circ}$ & 0.898 & $-3^{\circ} \pm 13^{\circ}$ & 0.966 & $-1^{\circ} \pm 9^{\circ}$ \\
July $65^{\circ} \mathrm{N}$ & - & - & 0.683 & $-71^{\circ} \pm 26^{\circ}$ & 0.903 & $-50^{\circ} \pm 13^{\circ}$ \\
July $15^{\circ} \mathrm{N}$ & - & & - & - & 0.905 & $-50 \pm 13^{\circ}$ \\
\hline
\end{tabular}

$80 \%$ confidence interval for coherency is $0.439 ; 95 \%$ confidence interval is 0.706 ; band with is 0.01 ; time step is $2 \mathrm{ka}$; negative phase angles indicate phase lags of $\mathrm{KL} 11 \delta^{18} \mathrm{O}$ relative to reference record.

${ }^{\text {a}}$ From Vogelsang [1990].

trace the hydrography of the deeper water masses. The benthic $\delta^{18} \mathrm{O}$ record shows the same high-amplitude signal as the planktonic $\delta^{18} \mathrm{O}$ record (Figure 3 ). Even though the resolution of the benthic record is much lower due to lack of specimens, one can still observe the close correlation between $\delta^{18} \mathrm{O}$ maxima. As in the planktonic $\delta^{18} \mathrm{O}$ record the LGM values are the most positive values $(+4.7 \% 0)$ observed in the entire record. This suggests that the long-term climate signal (i.e., the sea level signal) was communicated from the surface to the deeper water masses. Converting the benthic isotope signal into salinity values, our measurements would correspond to approximately $55 \%$.

The accuracy of our salinity estimates depends not only on the applied correction for the $G$. ruber-C. acicula $\delta^{18} O$ offset but also on whether the modern $\delta_{w}$ s slope of 0.29 applies for the extreme hydrographic situation of the LGM and previous glacials. As Rohling [1994] hypothesizes, the oxygen isotope fluxes in the Red Sea may have been different during the LGM due to evaporation fluxes under enhanced wind stress. If true, the associated enrichment in ${ }^{18} \mathrm{O}$ of the surface waters due to evaporation would have dropped (Rohling suggests a drop of some $50 \%$ ) even if the rates of evaporation remained the same as todays. This would imply that our salinity estimates, which were calculated using the present relationship between waterloss to evaporation and ${ }^{18} \mathrm{O}$ enrichment, would underestimate the $\delta^{18} \mathrm{O}$ and salinity enrichment during full glacial periods. That is, the salinity increase during periods of maximum glaciation would have been even larger than the increase suggested above of nearly $16 \%$.

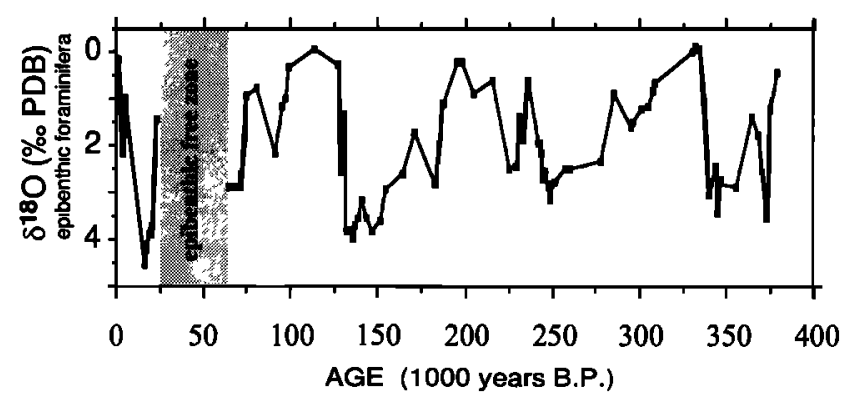

Figure 3. pibenthic $\delta^{18} \mathrm{O}$ record from Hanzawaia sp. and Cibicides mabahethi. The record shows the same highamplitude pattern as the planktonic $\delta^{18} \mathrm{O}$ record shown in Figure 2a. The epibenthic free zone characterizes an interval during isotope stage 3 .
The direct correlation between maximum inferred salinity and full - glacial climate clearly suggests that sea level was the driving force behind the long-term salinity change [Thunell et al., 1988]. As sea level falls, the geometry of Bab el Mandeb (the strait connecting the Red Sea and the Gulf of Aden) becomes narrower, and water mass exchange between the Red Sea and the open ocean becomes even more restricted than today. Thus salt builds up in the Red Sea until an equilibrium is reached between salt import from the open ocean and freshwater loss (due to evaporation) and salt export from the Red Sea through outflow to the Gulf of Aden. Figure 4 shows the correlation between sea level and water mass salinity in the Red Sea. This correlation was calculated using the numerical model of Assaf and Hecht [1974], which is similar to other sea strait models [e.g. Anati, 1980; Bryden and Stommel, 1984; Bryden and Kinder, 1991] and predicts Red Sea salinity as a function of the sea strait's geometry, evaporation, and salt import. For the model's parameterization we used a modern surface area of the Red Sea of $424 \times 10^{3} \mathrm{~km}^{2}$, width and depth of Bab el Mandeb of $37 \mathrm{~km}$ and $160 \mathrm{~m}$, respectively, and a salinity of $36.6 \%$ of the inflowing surface waters. For the LGM sea level was set to $-120 \mathrm{~m}$ [Fairbanks, 1989; Brachert and Dullo, 1991], surface area to $219 \times 10^{3}$ $\mathrm{km}^{2}$ (i.e. $50 \%$ of the modern surface area), and width and depth of Bab el Mandeb to $12 \mathrm{~km}$ and $40 \mathrm{~m}$; water loss to evaporation was kept constant (i.e., $6.3 \times 10^{-8} \mathrm{~m} \mathrm{~s}^{-1}$ ) [Thunell et al., 1988; Rohling, 1994]. All parameters were changed linearily between their LGM and modern values as sea level was raised from glacial maximum low stand to interglacial high stand.

The commonly preferred depth at Bab el Mandeb is $137 \mathrm{~m}$ [Locke and Thunell, 1988; Bethoux, 1988], which would imply a LGM sill depth of $17 \mathrm{~m}$. Using such shallow sill depth, the Assaf and Hecht model is no longer stable and breaks down. Thunell et al. [1988] used a LGM sill depth of $60 \mathrm{~m}$ to be able to run the Assaf and Hecht model. Based on the sporadic presence of planktonic foraminifera and continuous occurrence of benthic foraminifera in low numbers throughout the LGM [Risch, 1976; Locke and Thunell, 1988; Yusuf, 1978], we conclude that a moderate water exchange through Bab el Mandeb still existed at the LGM and that the sill must have been tectonically uplifted since then. Despite these uncertainties, we use the Assaf and Hecht model to estimate the effects of global sea level change on the Red Sea's salinity.

Using the above parameterization (including a sill depth of $60 \mathrm{~m}$ during the LGM) a LGM sea level fall of $120 \mathrm{~m}$ would 


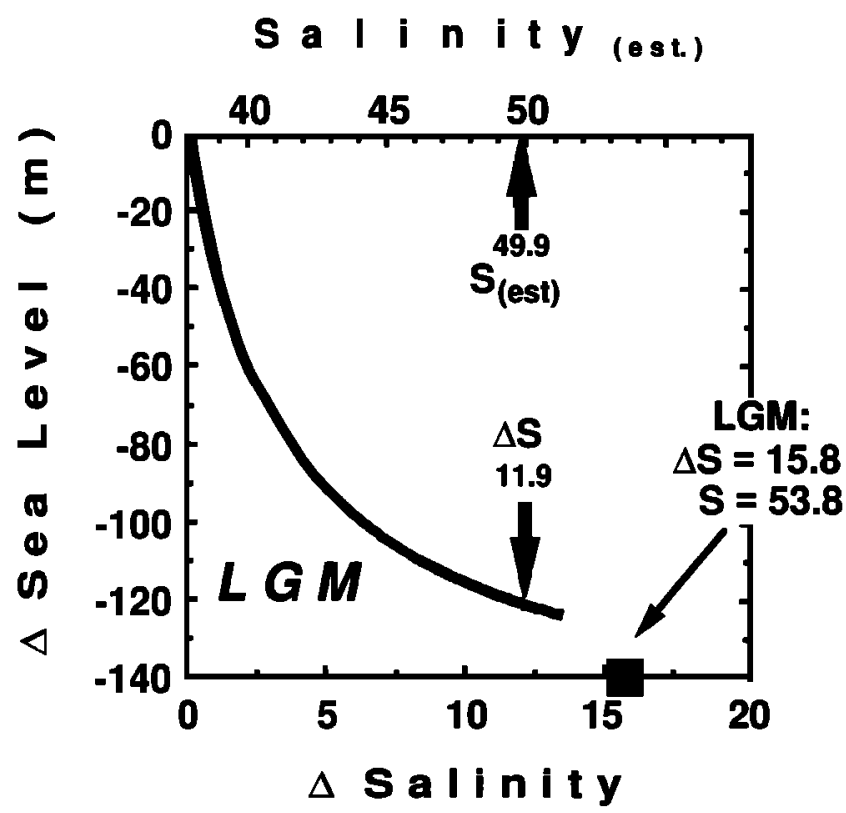

Figure 4. Red Sea salinity as a function of global sea level. The salinity was estimated using the empirical sea strait model of Assaf and Hecht [1974]. Model parameters are given in the text. The glacial-interglacial $\delta^{18} \mathrm{O}$ amplitude of $5.5 \% 0$ implies a salinity increase of nearly $16 \%$ at the LGM. This high salinity is not predicted by the water balance model, pointing to climatically - driven salinity changes (evaporation over precipitation) which add to the sea level effect on the Red Sea's salinity changes.

result in a salinity increase of $12 \%$ bringing salinities in the central Red Sea to 50\% (Figure 4). The numerically derived salinity increase is about $4 \%$ below the estimate derived from the planktonic $\delta^{18} \mathrm{O}$ enrichment during the LGM. This discrepancy may be a result of our model parameterization, namely, the assumed depth of the Bab el Mandeb sill. However, as we will show below, the presence of distinct $\delta^{18} \mathrm{O}$ and faunal anomalies throughout our records implies that local climatic influences affected salinity in addition to the dominant sea level forcing.

\section{Spectral Analysis}

In order to compare statistically our planktonic $\delta^{18} \mathrm{O}$ record with the record of climate change we performed cross-spectral analysis using the record of $65^{\circ} \mathrm{N}$ July insolation [Berger and Loutre, 1991] as climatic forcing reference (Figure 5). We have smoothed the planktonic $\delta^{18} \mathrm{O}$ record with a Gaussian filter applying a $6 \mathrm{kyr}$ wide filter window and an effective time step of $2 \mathrm{kyr}$. The cross-spectral procedure follows standard routines described by Imbrie et al. [1984]. The cross spectrum shows siginificant coherence between the KL11 planktonic $\delta^{18} \mathrm{O}$ record and $65^{\circ} \mathrm{N}$ July at the orbital obliquity (41 kyr) and precession (23 kyr) periods (Figure 6). Highlatitude insolation variance is low in the orbital eccentricity period (100 kyr; (Figure 6, Table 2)), and thus the cross spectrum cannot evaluate the coherencies in this frequency band. Using the SPECMAP $\delta^{18} \mathrm{O}$ stack [Imbrie et al., 1984] as a reference shows high coherencies at all three primary orbital periods (Table 2). This high coherency is expected because we have used the SPECMAP record to calibrate the age model for core KL11. The high coherencies and low phase angles confirm that the age model of core $\mathrm{KL} 11$ reproduces the orbital SPECMAP age model to within 0.4-1.3 ka (Table 2).

The cross -spectrum shows phase differences between $\delta^{18} \mathrm{O}$ and insolation of $71^{\circ} \pm 26^{\circ}$ and $50^{\circ} \pm 13^{\circ}$ in the orbital obliquity and precession bands which are equivalent to time lags of $8 \mathrm{kyr}$ and $3 \mathrm{kyr}\left(\delta^{18} \mathrm{O}\right.$ lags insolation (Figure 5, Table 2)). Using June instead of July $65^{\circ} \mathrm{N}$ insolation as the forcing reference would shift the lag between $\delta^{18} \mathrm{O}$ and insolation in the precession band to $5 \mathrm{kyr}$. These are established lags between orbitally tuned climate proxies and climate forcing [Imbrie et al., 1984]. The planktonic $\delta^{18} \mathrm{O}$ record from core $\mathrm{K} L 11$ thus directly reproduces the global climate record and confirms that the record primarly shows global climate variation with a strong overprint of sea level effects which are documented in the greatly enhanced amplitudes of the $\delta^{18} \mathrm{O}$ signal.

Spectral analysis of paleoclimatic records from the Arabian Sea has shown significant coherence between biological, chemical, and lithogenic tracers and insolation variance in the precession band with a phase lag of $122^{\circ}$ corresponding to a time lag of $8 \mathrm{kyr}$ [Clemens and Prell, 1990; Clemens et al., 1991]. This has been used as evidence for a strong contribution of monsoonal circulation to the paleoclimatic signals in response to radiative forcing, cross-equatorial heat transport and heat release from the Tibetan plateau [Clemens et al., 1991].

At present we have no independent tracer from core $\mathrm{KL} 11$ to test the monsoonal influence on the Red Sea area. Variance in the precession band is slightly enhanced in the planktonic $\delta^{18} \mathrm{O}$ record compared to the SPECMAP stack (Figure 6). Since the KL11 $\delta^{18} \mathrm{O}$ record is phase-locked to global ice volume by using the SPECMAP age model, we cannot use this enhanced variance as independent evidence for monsoonal signals. However, in view of the presence of strong monsoonal signals in paleoclimatic records from the Arabian Sea [e.g., Prell, 1984; Kutzbach and Street-Perrot, 1985; Prell and van Campo, 1986; Anderson and Prell, 1992; Prell and Kutzbach, 1992] just outside the Red Sea, we speculate that the enhanced precessional $\delta^{18} \mathrm{O}$ variance in core $K L 11$, in conjunction with faunal anomalies (see below), is a preliminary indication of paleomonsoon signals in the Red Sea.

\section{Faunal Records of Paleohydrography and Paleoclimate}

The abundance pattern of planktonic foraminifera along core KL11 may be used as an independent indicator of paleosalinity, since most foraminiferal species have a narrow range of tolerance with respect to salinity. The abundance of planktonic foraminifera closely follows the $\delta^{18} \mathrm{O}$-climate signal in that abundances decrease from full - interglacial to full glacial conditions when salinities increase (Figure 7a). The distribution pattern shows short-term abundance maxima during high sea level stands, which correlate with low, closeto-modern salinity values as deduced from the planktonic $\delta^{18} \mathrm{O}$ record, implying that rich planktonic communities dominated during humid climates when salinity was low due to increased moisture transport by the monsoonal winds. During periods of enhanced aridity and increased salinity the planktonic community was decreased and dominated by Globigerinoides 

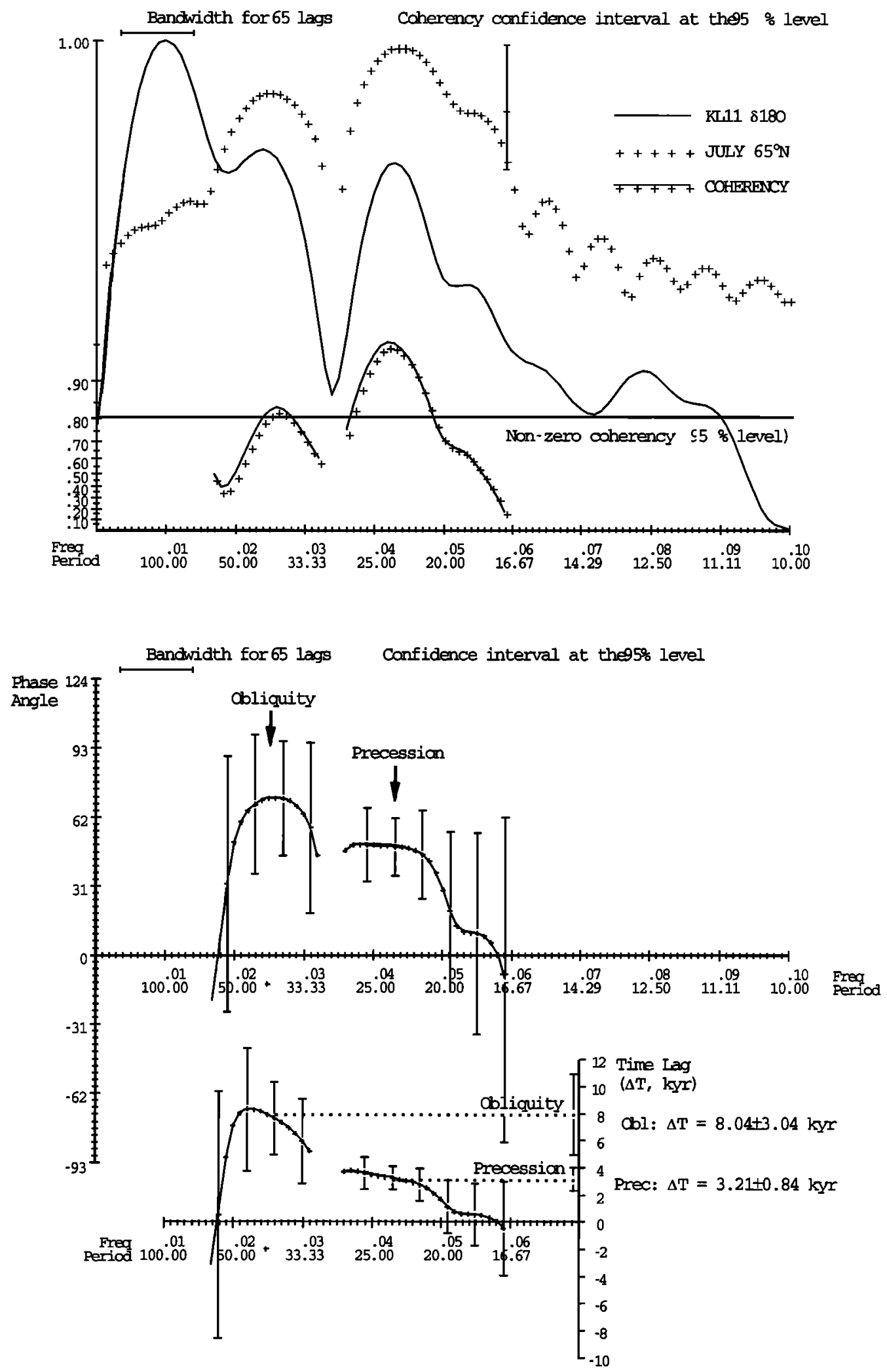

Figure 5. Cross-spectral analysis of planktonic $\delta^{18} \mathrm{O}$ from core $\mathrm{KL} 11$ and $65^{\circ} \mathrm{N}$ July insolation calculated from algoriths of Berger and Loutre [1991]). Both time series are coherent at the orbital obliquity and precession periods. Phase lags of $70^{\circ}$ and $50^{\circ}$ are observed for $\mathrm{KL} 11 \delta^{18} \mathrm{O}$ which are equivalent to time lags of $8 \mathrm{kyr}$ and $3 \mathrm{kyr}$. These are characteristic lags between $\delta^{18} \mathrm{O}$ and climatic forcing [e.g. Imbrie et al., 1984], thus pointing to high-latitude climate as the primary control on $\delta^{18} \mathrm{O}$ in core KL11. Positive phase angles indicate phase lags. 

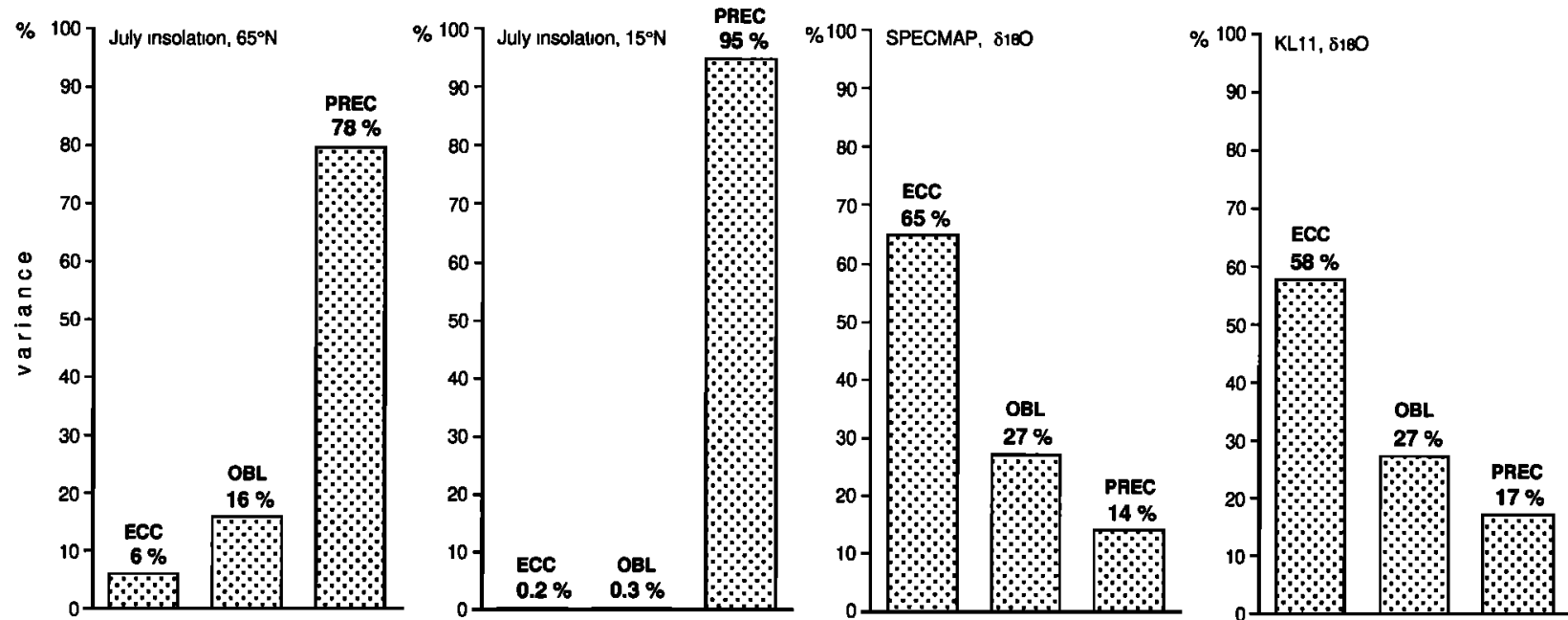

Figure 6. Percent contribution of variance in the eccentricity (ECC), obliquity (OBL), and precession (PREC) periods to the total variance of July insolation at $65^{\circ}$ and $15^{\circ} \mathrm{N}$, and of $\delta^{18} \mathrm{O}$ in the SPECMAP stack [Imbrie et al., 1984] and along core KL11. Variance in the orbital precession band is slightly enhanced in $\mathrm{KL} 11 \delta^{18} \mathrm{O}$, pointing to low-latitude climatic forcing, possibly monsoonal variability.
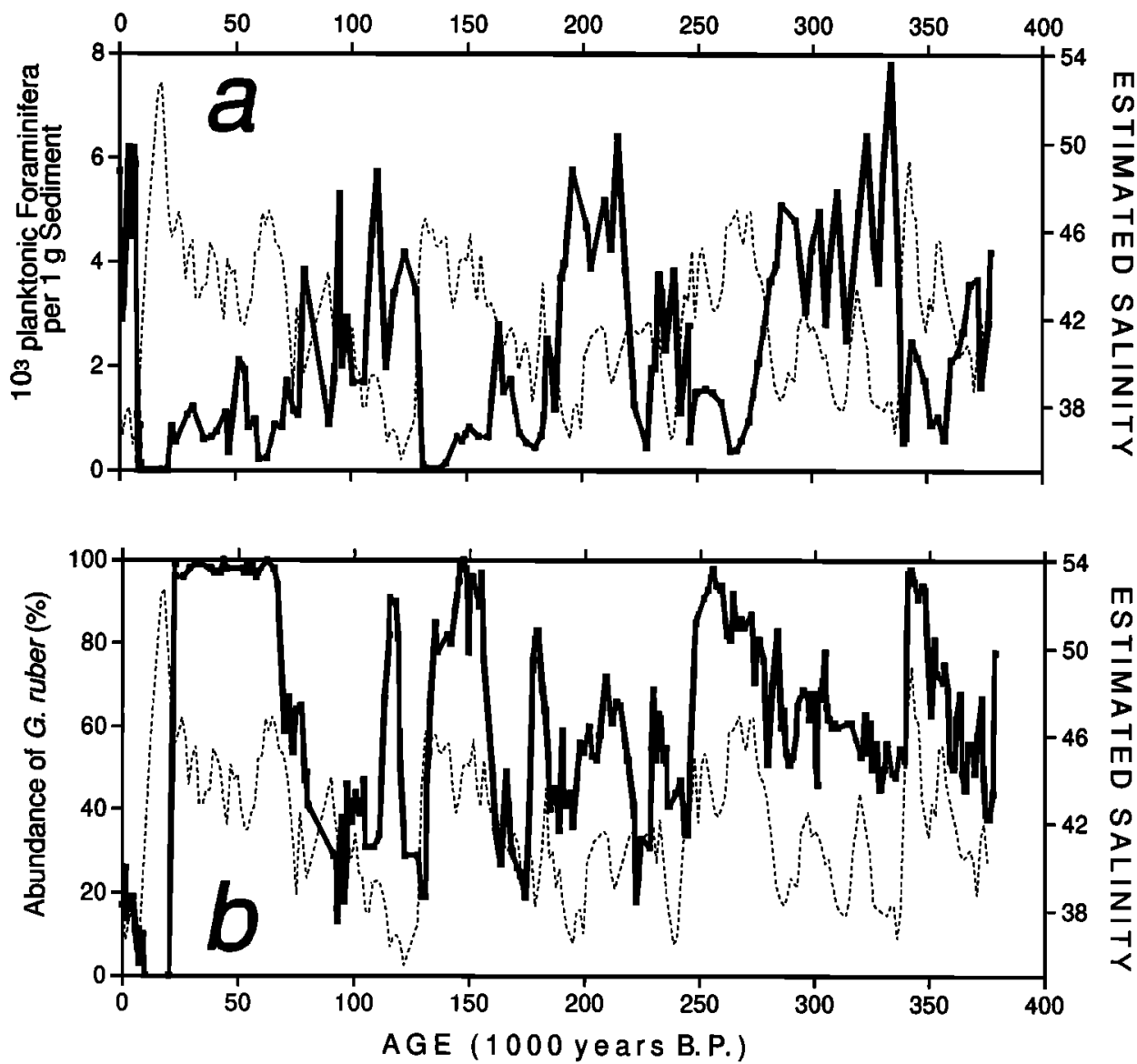

Figure 7. (a) Correlation of planktonic foraminifera with salinity. The abundance distribution of planktonic foraminifera (solid line) follows the climatic signal along core KL11 and correlates with the inferred changes of paleosalinity (dotted line). The increase of salinity during full - glacial periods resulted in an abundance decrease of planktonic foraminifera. (b) Correlation of Globigerinoides ruber with salinity. G. ruber tolerates maximum salinities up to 49\%o [Bijma et al., 1990]. The abundance pattern of this species (solid line) confirms our paleosalinity reconstruction (dotted line) in that it disappeared only during the LGM when our inferred salinities increased to $53 \%$ or more. 
ruber, which is one of the most flexible species among planktonic foraminifera and can tolerate salinities between 22 and 49\%o [Bijma et al., 1990]. The continuous presence of $G$. ruber throughout the record, except during the LGM (Figure $7 \mathrm{~b})$, supports our paleosalinity reconstruction in that it implies that salinities never exceeded $49 \%$. It is only during the LGM, that $G$. ruber disappears from the central Red Sea. Our salinity reconstructions imply a paleosalinity above $53 \%$ for the LGM which would have been above the upper limit of the salinity range which this species can tolerate in laboratory cultures, thus causing $G$. ruber to vanish.

By identifying the abundancy of $G$. ruber, we obtained a pattern which may reflect the variations of the incoming nutrient rich intermediate water driven by the SW monsoon (Morcos, 1970). Today this water mass reaches up to $18^{\circ} \mathrm{N}$ and affects the distribution pattern of planktonic foraminifera. During times of weaker or stronger monsoon activity, this boundary may have shifted farther north (stronger monsoon) or south (weaker monsoon). However, this can be verified only by investigating cores in areas north and south of our core location, which will be done in the future.

A general trend toward lower glacial-interglacial amplitudes is observed in total abundance variations of planktonic foraminifera, which goes along with a trend toward more enhanced changes in $G$. ruber, may indicate a general increase in Red Sea salinities potentially in conjunction with a tectonic uplift of the sill at Bab el Mandeb during the past $380 \mathrm{kyr}$.

Between 13 and $21 \mathrm{ka}$ all planktonic foraminifera vanished from the Red Sea resulting in a so-called aplanktonic zone (Figure 7) [e.g., Locke and Thunell, 1988; Almogi-Labin et al., 1991]. During this period, lithified aragonite layers (LAL) up to $1 \mathrm{~m}$ thick [Milliman et al., 1969] were deposited and seem to be almost barren of planktonic foraminifera. It is only $1 \mathrm{~cm}$ above the $\mathrm{LAL}$, or about 180 years after the aplanktonic zone [cf. Almogi-Labin et al., 1991] that the first planktonic foraminifera reappeared at site KL11 and another $1-4 \mathrm{~cm}$, or up to 720 years after the end of the aplanktonic zone, that the planktonic foraminiferal community was almost fully reestablished. Apparently, environmental conditions improved very rapidly after $13 \mathrm{ka}$ due to rising sea level. Thus the foraminiferal fauna appeared again, but was present still in low abundances. Between 9 and $8 \mathrm{ka}$, when climatic conditions were at an optimum, the total planktonic and benthic fauna was fully reestablished.

During the last deglaciation east African climates changed from arid to fully humid conditions in response to an orbitally - driven increase of monsoonal rainfall [Kutzbach and Guetter, 1986; Pachur and Kröpelin, 1987; COHMAP Members, 1988; Pachur et al., 1990; Bonnefille et al., 1990; Gasse et al., 1990; Lezine and Casanova, 1991]. Even though the Red Sea today receives little or no fresh water from surrounding land areas, we speculate that increased humidity may have lowered evaporation rates over the Red Sea, thereby enhancing the effects of sea level rise on lowering salinities. This would have contributed to the speed at which the faunal community reestablished itself during the last deglaciation. Together with the presence of strong precessional variance in the $\delta^{18} O$ record from core $\mathrm{KL} 11$, this leads us to conclude that during the past $380 \mathrm{kyr}$ not only was the hydrography of the Red Sea controlled by global sea level variation but that variations in monsoonal strength also contributed to the fresh water balance by altering humidity and evaporation.

\section{Summary}

Core KL11 from the central Red Sea provides a continuous sedimentary record for the last $380 \mathrm{kyr}$ showing glacialinterglacial $\delta^{18} \mathrm{O}$ amplitudes that are up to 3 times higher than those of the mean-ocean $\delta^{18} O$ record. Correcting the planktonic $\delta^{18} O$ record for mean-ocean ${ }^{18} \delta O$, we derive salinities of up to $53 \%$ or even slightly higher for the LGM. These measured and calculated values are approximately $3 \%$ o higher than previously assumed values. During the glacial maximum, isotope stage 6 and 10 salinities were also significantly increased but lower than the maximum values inferred for the LGM. The planktonic fauna varied along with the salinity changes and was drastically reduced during glacial maxima due to the high salinity levels; during the LGM an aplanktonic zone developed owing to the highest salinities inferred for the entire $380 \mathrm{kyr}$ period which apparently resulted in extremely hostile conditions. Global sea level variations are the main factor in controling the Red Sea's salinity. However, sea level cannot explain the full range of salinitiy changes deduced from our isotope data. An additional climatically - driven component is needed to add to the sealevel-driven salinity changes. This component is conceivably linked to variations in monsoonal strength. Support for this contention is provided by enhanced variance of planktonic $\delta^{18} \mathrm{O}$ in the orbital precession band.

Acknowledgements. We thank the master, crew and scientists aboard R/V Meteor (cruise 5) for their help and assistance. We also thank I. Breitinger, J. Erbacher, G. Schmiedl, D. Mühlen, and R. Ott, (all at University of Tübingen), F. Clasen, B. Gehrke, U. Meliß (all at University of Göttingen) and H.H. Cord, I. Klein, and H. Hecht (all at University of Kiel) for their help during data acquisition and in preparing the manuscript and W. Prell, Brown University, for using freely distributed software. We are also grateful to $D$. Anderson and an anonymous reviewer for constructive criticism which helped to improve this manuscript. This research was funded by the Deutsche Forschungsgemeinschaft under contracts He 697/7 and Me 267/28, and the G.I.F., the German-Israeli Foundation for Scientific Research and Development.

\section{References}

Almogi-Labin, A., Stratigraphic and paleoceanographic significance of late Quatemary pteropods from deep-sea cores in the Gulf of Aqaba (Elat) and northermmost Red Sea, Mar.Micropaleontol., 7, 53-73,1982.

Almogi-Labin, A., B.Luz, B.and J.-C. Duplessy, Quatemary paleo-oceanography, pteropod preservation and stable-isotope record of the Red Sea. Palaeogeogr. Palaeoclimatol. Palaeoecol., 75, 195-211, 1986.

Almogi-Labin, A., Ch. Hemleben, D. Meischner, and $\mathbf{H}$. Erlenkeuser, Paleoenvironmental events during the last 13,000 years in the central Red Sea as recorded by Pteropoda: Paleoceanography, 6, 83-98, 1991.

Anati, D.A., A parameterization of the geometry of sea straits, Oceanol. Acta, 3, 395-397, 1980.

Anderson, D.M., and W.L. Prell, The structure of the southwest monsoon winds over the Arabian Sea during the Late Quatemary: Observations, simulations, and marine geologic evidence, J. Geophys. Res., 97, 481-487, 1992.

Assaf, G., and A. Hecht, Sea straits: A dynamical model, Deep Sea Res., 21, 947-958, 1974 
Berger, A., and M.F. Loutre, Insolation values for the climate of the last 10 million years, Quat. Sci. Rev., 10, 297-317, 1991.

Berggren, W.A., and A. Boersma, Late Pleistocene and Holocene planktonic foraminifera from the Red Sea, in Hot Brines and Recent Heavy Metal Deposits in the Red Sea, edited by E.T. Degens and D.A. Ross, pp. 282-298, Springer-Verlag, New York, 1969.

Bethoux, J.P., Red Sea geochemical budgets and exchanges with the Indian Ocean, Mar. Chem., 24, 83-92, 1988.

Bijma, J., W.W. Faber Jr., and Ch. Hemleben, Temperature and salinity limits for growth and survival of some planktonic foraminifers in laboratory cultures, J. Foraminiferal Res., 20, 95 $116,1990$.

Bonnefille, R., J.C. Roeland, and J. Guiot, Temperature and rainfall estimates for the past 40,000 years in equatorial Africa, Nature. 346, 347-349, 1990.

Brachert, T.C., and W.C. Dullo, Laminar micrite crusts and associated foreslope processes, Red Sea, J. Sediment. Petrol., 61, 354-363, 1991.

Bryden, H.L. and T.H. Kinder, Recent progress in strait dynamics, U.S. Natl. Rep. Int. Union Geod. Geophys. 1987-1990, Rev. Geophys., 29, 617-631, 1991.

Bryden, H. L., and H. M. Stommel, Limiting processes that determine basic features of the circulation in the Mediterranean Sea, Oceanol. Acta, 7, 289-296, 1984.

Chen, C., Pteropods in hot brine sediments of the Red Sea, in Hot Brines and Recent Heavy Metal Deposits in the Red Sea, edited by E.T. Degens and D.A. Ross, pp. 313-316, Springer-Verlag, New York, 1969.

Clemens, S.C. and W.L. Prell, Late Pleistocene variability of Arabian Sea summer monsoon winds and continental aridity: Eolian records from the lithogenic component of deep-sea sediments, Paleoceanography, 5, 109-145, 1990.

Clemens, S., W. Prell, D. Murray, G. Shimmield, and G. Weedon, Forcing mechanisms of the Indian Ocean monsoon, Nature, 353, 720-725, 1991.

CLIMAP Project Members, Seasonal reconstruction of the Earth 's surface at the last glacial maximum, Geal. Soc. Am., Map Chart Ser., $M C-36,1981$.

COHMAP Members, Climatic change of the last 18,000 years: Observations and model simulations, Science, 241, 1043-1052, 1988.

Craig, H., Isotopic composition and origin of the Red Sea and Salton Sea geothermal brines. Science, 154, 1544-1548, 1966.

Deuser, W.G. and E.T. Degens, O18/O16 and C13/C12 ratios of fossils from the hot-brine deep area of the central Red Sea, in Hot Brines and Recent Heavy Metal Deposits in the Red Sea, edited by E.T. Degens and D.A. Ross, pp. 336-347, Springer-Verlag, New York, 1969.

Deuser, W.G., E.H. Ross, and L.S. Waterman, Glacial and pluvial periods: Their relationship revealed by Pleistocene sediments of the Red Sea and Gulf of Aden, Science, 191, 1168-1170, 1976.

Fairbanks, R.G., A 17,000-year glacio-eustatic sea level record: Influence of glacial melting rates on the Younger Dryas event and deep-ocean circulation, Nature, 342, 637-642, 1989.

Gasse, F., R. Téhet, A. Durant, E. Gilbert, and J.-C. Fontes, The arid-humid transition in the Sahara and the Sahel during the last deglaciation, Nature, 346, 141-146, 1990.

Herman, Y., Evidence of climatic changes in Red Sea cores, in Means of Correlations of Quatemary Successions, Proceedings VII Congress International Association for Quatemary Research, vol. 8, edited by R.B. Morrison and H.E. Wright, pp. 325-348, Univ. of Utah Press, Salt Lake City, 1968.

Imbrie, J., J.D. Hays, D.G. Martinson, A. McIntyre, A.C. Mix, J.J. Morley, N.G. Pisias, W.L. Prell, and N.J. Shackleton, The orbital theory of Pleistocene climate: Support from a revised chronology of the marine $8^{18} \mathrm{O}$ recond, in Milankovitch and Climate, edited by A.L. Berger et al., pp. 269-305, D: Reidel, Norwell, Mass., 1984.

Ivanova, E.V., Late Quaternary biostratigraphy and paleotemperatures of the Red Sea and the Gulf of Aden based on planktonic foraminifera and pteropods. Mar. Micropaleontol., 9, 335-364, 1985.
Jasper, J.P., and W.G. Deuser, Annual cycles of mass flux and isotopic composition of pteropod shells settling into the deep Sargasso Sea, Deep Sea Res., 40, 653-669, 1993.

Kutzbach, J.E., and P.J. Guetter, The influence of changing orbital parameters and surface boundary conditions on climate simulations for the past 18,000 years, J. Atmos. Sci. , 43, 1726$1759,1986$.

Kutzbach, J.E.,, and F.A. Street-Perrot, Milankovitch forcing on fluctuations in the level of tropical lakes from 18 to $0 \mathrm{ka} \mathrm{BP}$, Nature, 317, 130-134, 1985.

Labeyrie, L. D., J.-C. Duplessy, and P.L. Blanc, Variations in mode of formation and temperature of oceanic deep waters over the past 125,000 years, Nature, 327, 477-482, 1987.

Lezine, A.-M., and J. Casanova, Correlated oceanic and continental records demonstrate past climate and hydrology of North Africa (0-140 ka), Geology, 19, 307-310, 1991.

Locke, $\mathrm{S}$. and R.C. Thunell, Paleoceanographic record of the last glacial/interglacial cycle in the Red Sea and Gulf of Aden. Palaeogeogr., Palaeoclimatol. Palaeoecol., 64, 163-187, 1988.

Milliman, J.D., D.A. Ross and T.-L. Ku, Precipitation and lithification of deep sea carbonates in the Red Sea, J. Sediment. Petrol., 39, 724-736, 1969.

Morcos, S.A., Physical and chemical oceanography of the Red Sea, Oceanogr. Mar. Biol. Annu. Rev., 8, 73-202, 1970.

Niitsuma, N., T. Oba, and M. Okada, Oxygen and carbon isotope stratigraphy at Site 723, Oman Margin, Proc. Ocean Drill. Program., Sci. Results, 117, 321-341, 1991.

Pachur, H.J., and S. Kröpelin, Wadi Howar: paleoclimatic evidence from an extinct river system in the southeastem Sahara, Science, 237, 298-300, 1987.

Pachur, H.J., S.T. Kröpelin, P. Hölzmann, M. Göschin, and N. Altmann, Late Quatemary fluvio-laccustrine environments of western Nubia, Berliner Geowiss. Abh., J, 120, 203-260, 1990.

Prell, W.L., Monsoonal climate of the Arabian Sea during the late Quaternary: a response to changing solar radiation, in Milankovitch and Climate, edited by A.L. Berger et al., pp. 349-366, D. Reidel, Norwell, Mass., 1984.

Prell, W.L. and J.E. Kutzbach, Sensitivity of the Indian monsoon to forcing parameters and implications for its evolution, Nature, 360, 647-652, 1992.

Prell, W.L. and E. van Campo, Coherent response of Arabian Sea upwelling and pollen transport to late Quaternary monsoonal winds, Nature, 323, 526-528, 1986.

Reiss, Z., B. Luz, A. Almogi-Labin, E. Halicz, A. Winter, M. Wolf, and D.A. Ross, Late Quatemary paleoceanography of the Gulf of Aqaba (Elat), Red Sea, Quat. Res., 14, 294-308, 1980.

Risch, H., Microbiostratigraphy of core-sections of the Red Sea, Geol. Jahrb. 17, 3-14,1976.

Rohling, E.J., Glacial conditions in the Red Sea, Paleoceanography, 9, 653-660, 1994.

Rossignol-Strick, M., African monsoons, an immediate climate response to orbital insolation, Nature, 304, 46-49, 1983.

Sirocko, F., M. Sarnthein, H. Erlenkeuser, H. Lange, M. Arnold, and J.-C. Duplessy, Century-scale events in monsoonal climate over the past 24,000 years, Nature, 364, 322-364, 1993.

Thunell, R.C., S.M. Locke, and D.F. Williams, Glacio-eustatic sealevel control on Red Sea salinity, Nature, 334, 601-604, 1988.

Vogelsang, E., Paläo-Ozeanographie des Europäischen Nordmeeres an Hand stabiler Kohlenstoff- und Sauerstoffisotope, Ph.D. thesis, Rep. SFB 313, 23, Kiel Univ. Kiel, Germany, 136 pp., 1990.

Yusuf, N., Mikropaläontologische und geochemische Untersuchungen an Bortkernen aus dem Roten Meer, Berl. Geowiss. Abh. Reihe A, 6, 1-77, 1978.

Zahn, R. and T. F. Pedersen, Late Pleistocene evolution of surface and mid-depth hydrography at the Oman Margin: Planktonic and benthic isotope records at ODP Site 724, Proc. Ocean Drill. Program, Sci. Results, 117, 291-308, 1991.

A. Almogi-Labin, Geological Survey of Israel, 30 Malkhe Yisrael St., 95501 Jerusalem, Israel. (e-mail: ALMOGI@mail.gsi.gov.il)

H. Erlenkeuser, Institut für Reine und Angewandte Kernphysik, C14- 
Labor, University of Kiel, Olshausenstr. 40-60, D-24098 Kiel, FR Germany. (e-mail: pke47@rz.uni-kiel.d400.de)

C. Hemleben (corresponding author) and B. Hiller, Institut und Museum für Geologie und Paläontologie, University of Tübingen, Sigwartstrasse 10, D-72076 Tübingen, FR Germany. (e-mail: Christoph. Hemleben@uni-tuebingen.de)

D. Meischner, Institut für Geologie und Palāontologie, Abt. SedimentGeologie, University of Göttingen, Goldschmidtstrasse 3, D-37077 Göttingen, FR Germany. (e-mail: dmeisch@gwdg.de)
R. Zahn, GEOMAR, Research Center for Marine Geosciences, Wischhofstr. 1-3, D-24148 Kiel, FR Germany. (e-mail: RZahn@Geomar. de)

(Received May 5, 1995; revised December 11, 1995; accepted December 20, 1995.) 